\title{
Nupela (Bacillariophyceae) in littoral rivers from south Brazil, and description of six new species of the genus
}

\author{
Priscila I. Tremarin*, Arielli Straube \& Thelma A. V. Ludwig
}

Botany Departament, Universidade Federal do Paraná, Centro Politécnico, P.O.Box 19031, 81531-990,

Jardim das Américas, State of Paraná, Brazil; *Corresponding author e-mail: ptremarin@gmail.com

\begin{abstract}
The genus Nupela is characterized mainly by structure of the areola and raphe system. Many species were described from tropical regions; however, few studies have been conducted on Brazilian environments. The goal of this article is to identify and describe the morphology of Nupela species, under light and electron microscopy, found in the rivers of the Atlantic Forest from southern Brazil. Twelve species were found, including six described as new: Nupela amabilis Tremarin et T. Ludwig, N. difficilis Straube, Tremarin et T. Ludwig, $N$. kocioleckii Straube, Tremarin et T. Ludwig, $N$. metzeltinii Tremarin et T. Ludwig, $N$. praecipuoides Tremarin et T. Ludwig and $N$. torganiae Tremarin et T. Ludwig, and a new combination, $N$. bicapitata (Hustedt) TREMARIN et T. LUDWIG.
\end{abstract}

Key words: Atlantic Forest, diatom, freshwater, lotic, taxonomy, ultrastructure

\section{INTRODUCTION}

Vyvermann \& COMPÈRE (1991) established the genus Nupela based on Nupela giluwensis described as new to Papua New Guinea. Nupela comprises small freshwater diatoms with finely ornamented valves, difficult to resolve only by light microscopy. The areola with external opening covered by hymenes is larger than the internal aperture and is pointed as a very stable taxonomic and typical character (SIVER et al. 2007; Spaulding \& EdLund 2008; Kulikovskiy et al. 2009). The external proximal ends of raphe usually are slightly expanded and internally somewhat curved or T-shaped (Spaulding \& EdLund 2008).

The genus Nupela has been expanded in the last decade including heterovalvar species beyond the isovalvar forms based on the type material, referring to the degree of raphe development in both valve faces of the frustule. The raphe may be fully developed on both valves or fully developed on one valve and lacks or shortened on the other valve (MONNIER et al. 2003; Potapova et al. 2003; Siver \& Hamilton 2005; Siver et al. 2007). Light microscopy is often insufficient for identification (Potapova et al. 2003). Distinctive valve features are generally only observed by electron microscopy.

So far, about 50 Nupela species are known (Catalogue of Diatom Names 2013; Buczkó et al. 2013; SALA et al. 2014). In Brazil, the Nupela species are documented mainly in floristic surveys (FARIA et al. 2010; CANANI et al. 2011; Moresco et al. 2011; SANTOS et al. 2011; Bes et al. 2012; BARTOZEK et al. 2013). Seven species has been documented (Tremarin et al. 2009) and a new species $-N$. pardinhoensis Bes, Torgan et ECTOR (BEs et al. 2012) has been established. Despite the difficulty to distinguish species by optical microscopy, the number of studies is relatively broad worldwide. New species have been recorded to France ( $N$. exotica Monnier, Lange-Bertalot et Bertrand), Poland ( $N$. marvanii WoJTAL), United States (N. neglecta Ponader, Lowe et Potapova, $N$. carolina Potapova et Clason, $N$. scissura Siver, Hamilton et Morales, $N$. potapovae Bahls, N. elegantula Potapova, N. frezelli Potapova), Russia (N. matrioschka Kulikovskiy, Lange-Bertalot et Witkowski), among others (Lange-Bertalot 1993; Lange-Bertalot \& Moser 1994; Monier et al. 2003; Potapova et al. 2003; Siver \& Hamilton 2005; Siver et al. 2007, 2010; KuLIKovskiY et al. 2009; WoJTAL 2009; Bahls 2011; Potapova 2011; BuczKó et al. 2013; Sala et al. 2014).

This paper aims to expand knowledge about the taxonomy of Nupela species based on samples collected in rheophilic environments from Brazilian Atlantic Forest, and well document the morphology of the taxa under light and electron microscopy.

\section{Material ANd Methods}

Diatom samples were collected from fifteen rivers along the Littoral basin of State of Paraná, located in the Atlantic Forest, Southern Brazil (Table 1). The headwaters of the selected rivers are located in the mountainous region or in 
the plain, flowing toward the Atlantic Ocean. The upper courses, located at the Serra do Mar, have rapid and clear waters (São João, Mãe Catira, Cachoeira, Nhundiaquara,

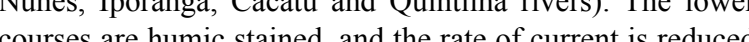
(Guaraguaçu, Sertãozinho, da Onça das Pombas, Cambaŕ do Salto and Colônia Pereira rivers) (BIGARELA 2001).

The samples were collected and fixed with TRANSEAU solution (1:1) (BICUDO \& MENEZES 2006). The phytoplankton were obtained with a plankton net $(25 \mu \mathrm{m}$ in mesh size) and periphyton samples were collected fron stems of aquatic macrophytes, sand and stones submerged. Periphytic diatoms were obtained by scraping the biofilm with a brush or by vigorous agitation of the sandy sedimen Samples were cleaned with potassium permangnate $\left(\mathrm{KMnO}_{4}\right.$ ) and hydrochloric acid ( $\mathrm{HCl}$ ) (SIMONSEN 1974), rinsed and mounted in Naphrax ${ }^{\circledR}($ R.I. $=1.74)$. Samples and slides are stored at the Herbarium of Universidade Federal do Paraná (UPCB) and at the Academy of Natural Sciences of Philadelphia (ANSP). Illustrations were performed using an optical microscope Olympus BX40 equipped with Olympus DP7I digital camera. Cleaned samples were (JEOL JSM 6360LV and TESCAN VEGA3 LMU, $15 \mathrm{kV}$ voltage and $8 \mathrm{~mm}$ working distance) and at transmission electron microscope-TEM (JEM microscope 1200EXII, voltage $80 \mathrm{kV}$ ), housed at the Electron Microscopical Center of Universidade Federal do Paraná. Abiotic variables $(\mathrm{pH}$, electrical conductivity and water temperature) were measured using a Consort C 335 equipment (Table 1). The erminology used in the descriptions followed Round et

\section{Results AND Discussion}

\section{Nupela amabilis Tremarin et T. Ludwig sp. nov.} (Figs 1-12)

Description: Frustules isovalvar, slightly asymmetric about apical plane. Valves linear-lanceolate with subrostrate apices, 11.5-12.2 $\mu \mathrm{m}$ long and 4.1-4.4 $\mu \mathrm{m}$ wide. Axial area linear. Central area asymmetric, reaching the margin on one side of valve, and limited by one or three areolae on the other side. Raphe slightly sinuous and complete on both valves. Proximal raphe externally expanded and internally hook-like. Terminal raphe ends curved to same side of the valve and internally ending in a small helictoglossa. Striae slightly radiate, ca. 50 in $10 \mu \mathrm{m}$, usually composed by discontinuous lines of areolae, 50 in $10 \mu \mathrm{m}$. Outer openings of areolae transapically elongate and the inner openings small, round to oval foramina.

Holotype: Slide UPCB 47513, Diatom collection of the Botany Department, Universidade Federal do Paraná, illustrated here in Figs 4-6.

Isotype: ANSP GC 26822.

Type material: Guaraguaçu river, Pontal do Paraná, State of Paraná, Brazil, $25^{\circ} 43^{\prime} 5.77^{\prime \prime S}, 48^{\circ} 33^{\prime} 26.81^{\prime \prime W}$ October 2003.
Taxonomical remarks: The isovalvarity is not a Wolfe et EdLund, N. potapovae BAHLS, N. subinvict (KRASSKE) Lange-Bertalot, $N$. tristis (Krasske) LANGe-Bertalot, $N$. vitiosa (Schimanski) Siver HAMILTON, and for $N$. amabilis (LANGE-BERTALOT al. 1996; SIVER \& HAMILTON 2005; SIVER et al. 2010; BAHLS 2011). Among them, only $N$. mutabilis has valve outline similar to N. amabilis, but differs in the rostrate apices and the $\mathrm{T}$-shaped internal proximal raphe end (SIVER et al. 2010).

Nupela amabilis differs from most species of genus by the internal proximal raphe ends strongly curved th hook. Similar raphe was also described to N. vitiosa, N. lapidosa (KRASSKE) Lange-Bertalot, $N$. neotropica (Hustedt) Lange-Bertalot, $N$. tenuicephala (HUSTEDT) LANGE-BERTALOT, N. acaciensi Vouilloud et SALA and $N$. catatumbensis Vouilloud et Plata-Díaz (Lange-Bertalot 1993; Lange-Bertalot \& Moser 1994; Siver \& HAMILTon 2005; WoJtal 2009; SALA et al. 2014). Despite raphe ends coincidence among mentioned species, isovalvar feature is foun only in N. acaciensis (SALA et al. 2014). The latter is distinguished from $N$. amabilis by lanceolate valve outline, cymbelloid symmetry, smaller central are and more elongated apices. Nupela vyvermanii LANGEBertalot illustrated by Werum \& LANGe-Bertalot (2004) has linear-lanceolate valve outline similar to Nupela amabilis, but has heterovalvar frustules with round central area, and its internal proximal ends of raphe are straight (WERUM \& LANGE-BerTaLOT 2004). Thus, the proposition of Nupela amabilis is justified by a unique set of characters, mainly consisting
of isovalvarity, linear-lanceolate valve outline and hook-shaped internal proximal raphe ends.

Nupela bicapitata (Hustedt) Tremarin et T. Ludwic comb. nov. (Figs 13-22)

icapitata Husted, Botaniska Notiser, 386 , fig. $68-71,1952$

Description: Frustules heterovalvar, slightly asymmetric about apical and transapical planes. Valves lanceolate with capitate apices, 19.2-22.9 $\mu \mathrm{m}$ long an 5.5-6.6 $\mu \mathrm{m}$ wide. Axial area lanceolate. Central are asymmetric, unilaterally expanded until the margin of the valve. Raphe slightly sinuous. One valve slightly convex, with long raphe slits. The oher valve, slightly concave, with very short raphe slits, restricted to the apices, widely separated proximal endings, and with linear depression along the axial area that resembles raphe on LM. Proximal raphe ends externally simple. Terminal raphe ends curved to same side of the valve. Striae slightly radiate becoming convergent toward apices, ca. 44 in $10 \mu \mathrm{m}$.

Thencen

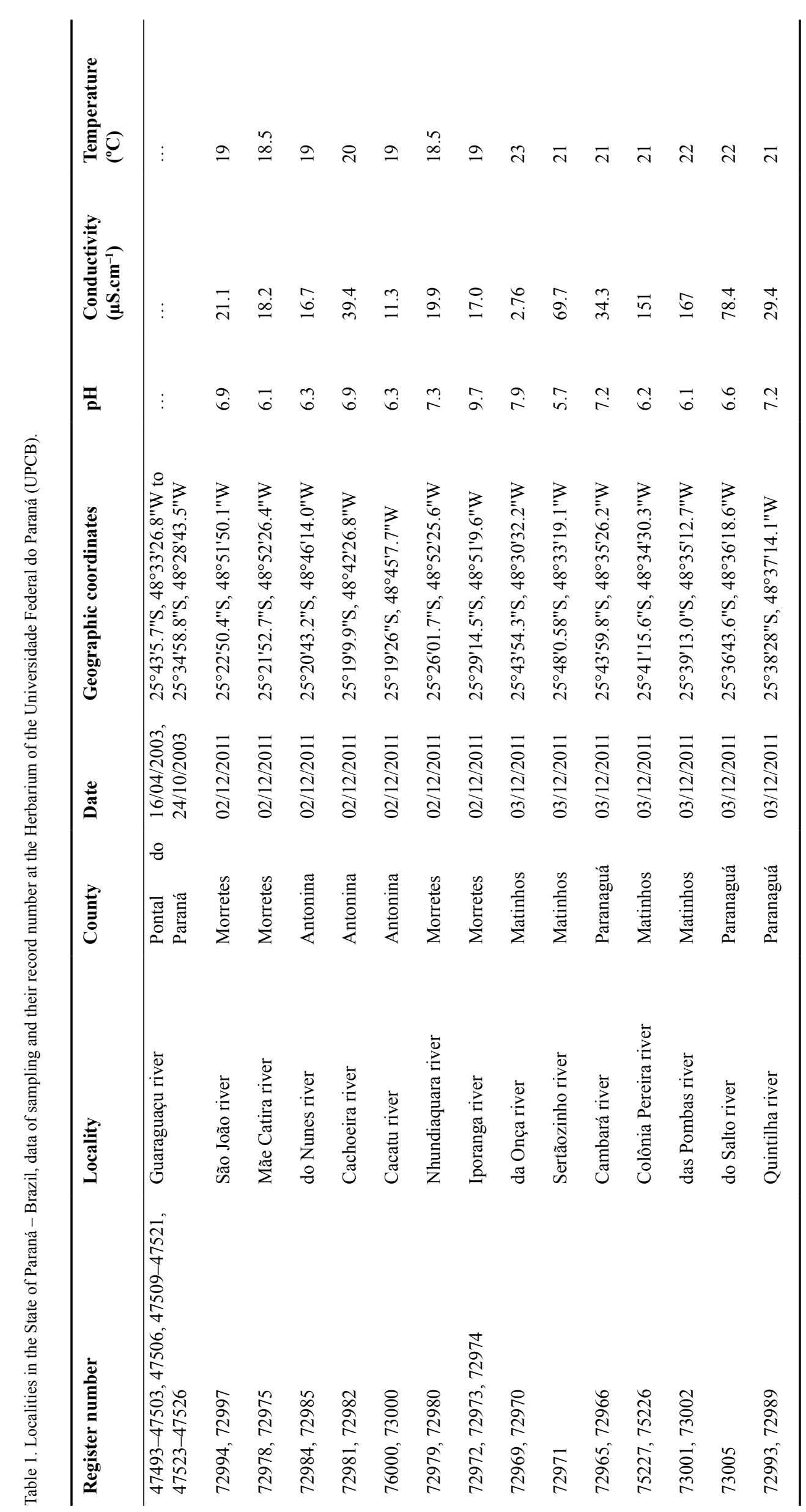


bicapitata described from a Norwegian sample as a monoraphid species by HUSTEDT (1952) and illustrated by Simonsen (1987, pl. 584, figs 1-11). The species is characterized by well developed raphe at one valve and an evident longitudinal linear depression at the other (Figs 13, 15, 18, 20). Nevertheless, SEM analyses of Brazilian material revealed a very reduced apical raphe at the supposed araphid valve. The new combination here performed is justified by the well documented typical Nupela areola and raphe.

This is the first subtropical record of this rarely reported species that besides type locality also occurred in North American low alkaline waters (CAMBURN \& Charles 2000).

Nupela decipiens (Reimer) Potapova (Figs 23-42) Basionym: Achnanthes decipiens ReiMER, Notulae Naturae, p. 2, pl.1, figs 2-5, 1966

Description: Frustules heterovalvar, slightly asymmetric about apical plane. Valves lanceolate with narrowly rostrate to subrostrate apices, 8.9-18.5 $\mu \mathrm{m}$ long and 4.1-5.9 $\mu \mathrm{m}$ wide. One valve with long raphe slits and the other valve araphid. Raphid valve with axial area lanceolate, central area widely rounded. Proximal raphe ends externally expanded and internally simple. Terminal raphe ends curved to same side of the valve and internally ending in a small helictoglossa. Araphid valve with axial area widely lanceolate, externally ornamented by several irregular depressions and a longitudinal one that resembles a raphe in LM internally with slits occluded near the apices. Central area widely lanceolate, not reaching the valvar margin. Transapical striae radiate, 36-40 in $10 \mu \mathrm{m}$, composed by continuous lines of areolae, ca. 52 in $10 \mu \mathrm{m}$. Inner openings of areolae small, round to oval.

Taxonomical remarks: The morphometric variation of $N$. decipiens in the Brazilian specimens agrees with that given by Potapova (2013) to USA. This register from Guaraguaçu river is the first record of the taxon to South America.

Nupela difficilis Straube, Tremarin et T. Ludwig sp. nov. (Figs 43-54)

Description: Frustules heterovalvar, slightly asymmetric about apical and transapical planes. Valves lanceolate with subrostrate apices, $8.8-14.8 \mu \mathrm{m}$ long and 4.1-5.9 $\mu \mathrm{m}$ wide. Axial area lanceolate. Central area asymmetric, unilaterally reaching the valve margin. Raphe on both valves. One valve with long raphe slits. The other valve with shorter raphe slits and separated proximal endings. Proximal raphe ends internally simple. Terminal raphe ending in a smal helictoglossa. Transapical striae slightly radiate, 40 in $10 \mu \mathrm{m}$, composed by continuous lines of areolae, 48$50 \mathrm{em} 10 \mu \mathrm{m}$. Inner openings of areolae small-round.

Holotype: Slide UPCB 72984, Diatom collection of the Botany Department, Universidade Federal do Paraná, illustrated here in Figs 48-49.

Isotype: ANSP GC26823

Type material: Do Nunes river, Antonina, State of araná, Brazil, 2520'43.2"S, 4846'14.0"W, December 2011

Taxonomical remarks: Nupela difficilis is similar to $N$. decipiens in valve dimensions, shape of apices and raphe ends, but the latter differs by the monoraphid frustule and central area shape (Potapova 2013). Nupela vyvermanii described and illustrated by LANGE-BERTALOT in MOSER et al. (1998) differs of $N$. difficilis by the smaller central area and lower density of striae ( 32 in $10 \mu \mathrm{m}$ ), besides convergent striae at the apices (Werum \& Lange-Bertalot 2004, pl. 25, fig 3-6). Nupela cf. vyvermanii LANGE-BERTALOT found by Alfinito \& Lange-Bertalot (2013, figs 65, 66) from Sierra Leone resembles $N$. difficilis in the valve size (length 14-15 $\mu \mathrm{m}$ and width 4-5 $\mu \mathrm{m}$ ) and apices shape, distinguishing by the lower number of striae (ca. 30 in $10 \mu \mathrm{m}$ ) and central area not reaching to valve margin. Nupela difficilis is mainly characterized by the valve outline, apices and central area contour, also by the traight proximal raphe ends in the inside valve.

Nupela exotica Monnier, Lange-Bertalot et Bertrand (Figs 55-65)

Description: Frustules heterovalvar, slightly asymmetric about apical plane. Valves elliptical lanceolate with rounded to subrostrate apices, 10.4 $15.2 \mu \mathrm{m}$ long and 4.4-5.2 $\mu \mathrm{m}$ wide. Axial area straight and narrow. Central area reduced. Raphe on both valves, slightly sinuous. Raphe slits well developed along one valve and shortened at the other. Proxima raphe ends externally expanded and internally simple. Terminal raphe ends curved to same side of the valve and internally ending in a small helictoglossa. Transapical striae straight to slightly radiate, $38-40$ in $10 \mu \mathrm{m}$, composed by discontinuous lines of areolae, ca. 23 in $10 \mu \mathrm{m}$. Outer openings of areolae transapically elongate and inner openings small, round to oval.

Taxonomical remarks: The exemplars of $N$. exotica analyzed in the Brazilian samples were wider than those recorded by MoNNIER et al. (2003, width 3.0-4.1 $\mu \mathrm{m})$, however other frustule features were identical to the type material. The irregular striation pattern of $N$. exotica resembles that of $N$. pardinhoensis, recently species described to Southern Brazil. Nupela pardinhoensis differs to $N$. exotica mainly by the shortened raphe slits on one valve and more separated proximal endings (MonNIER et al. 2003, Bes et al 2012). In Brazil, this species was cited by Tremarin et al. (2009)

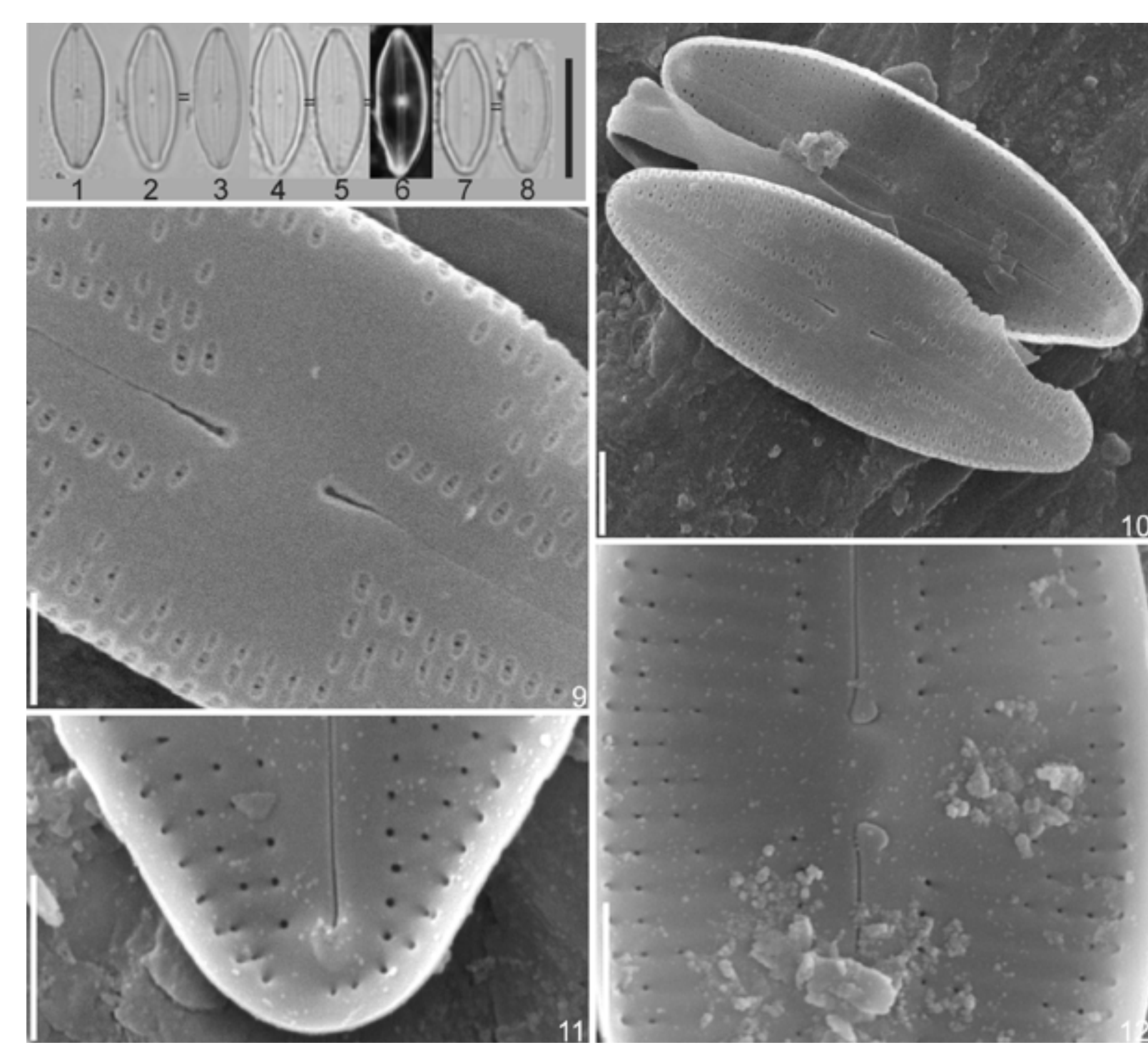

Figs 1-12. Nupela amabilis TREMARIN et T. LudwiG, LM (1-8) and SEM (9-12): (4-6) Holotype; (9) Detail of central region of valve in extern

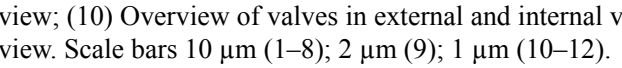

Nupela kociolekii Straube, Tremarin et T. Ludwig sp. nov. (Figs 66-83)

Description: Frustules heterovalvar, slightly asymmetric about apical plane. Valves ellipticallanceolate with narrowly subrostrate apices, 9.4-14.1 $\mu \mathrm{m}$ long and $4.7-5.9 \mu \mathrm{m}$ wide. Axial area lanceolate, sometimes with delicate depressions. Central area asymmetric, unilaterally reaching the valve margin, sometimes a c-letter area appears under LM. Raphe on both valves, slightly sinuous. One valve with long raphe slits. The other valve with shorter raphe slits and more separated proximal raphe endings. Proximal raphe ends externally expanded and internally hookshape. Terminal raphe ends curved to same side of the valve and internally ending in small helictoglossa Transapical striae radiate, 30 in $10 \mu \mathrm{m}$, composed by continuous lines of areolae, ca. 50 in $10 \mu \mathrm{m}$. Outer openings of areolae transapically elongate and inner openings small and round.
Etymology: This species is dedicated to Dr. Patrick KOCIOLEK, University of Colorado.

Holotype: Slide UPCB 72984, Diatom collection of the Botany Department, Universidade Federal do arana, illustrated here in Figs 66-67.

sotype: ANSP GC26823.

Type material: Do Nunes river, Antonina, State of 2011

Taxonomical remarks: Nupela kociolekii is more closely related to $N$. difficilis with respect to the degree of development of the raphe and by the shape of apices. Although both species have occurred in the same samples, these can be differentiated by the proximal aphe ends, and number of striae. The striae of $N$. difficilis are almost inconspicuous in LM because of arrangement ( 40 in $10 \mu \mathrm{m})$, furthermore the internal proximal raphe ends are straight. 


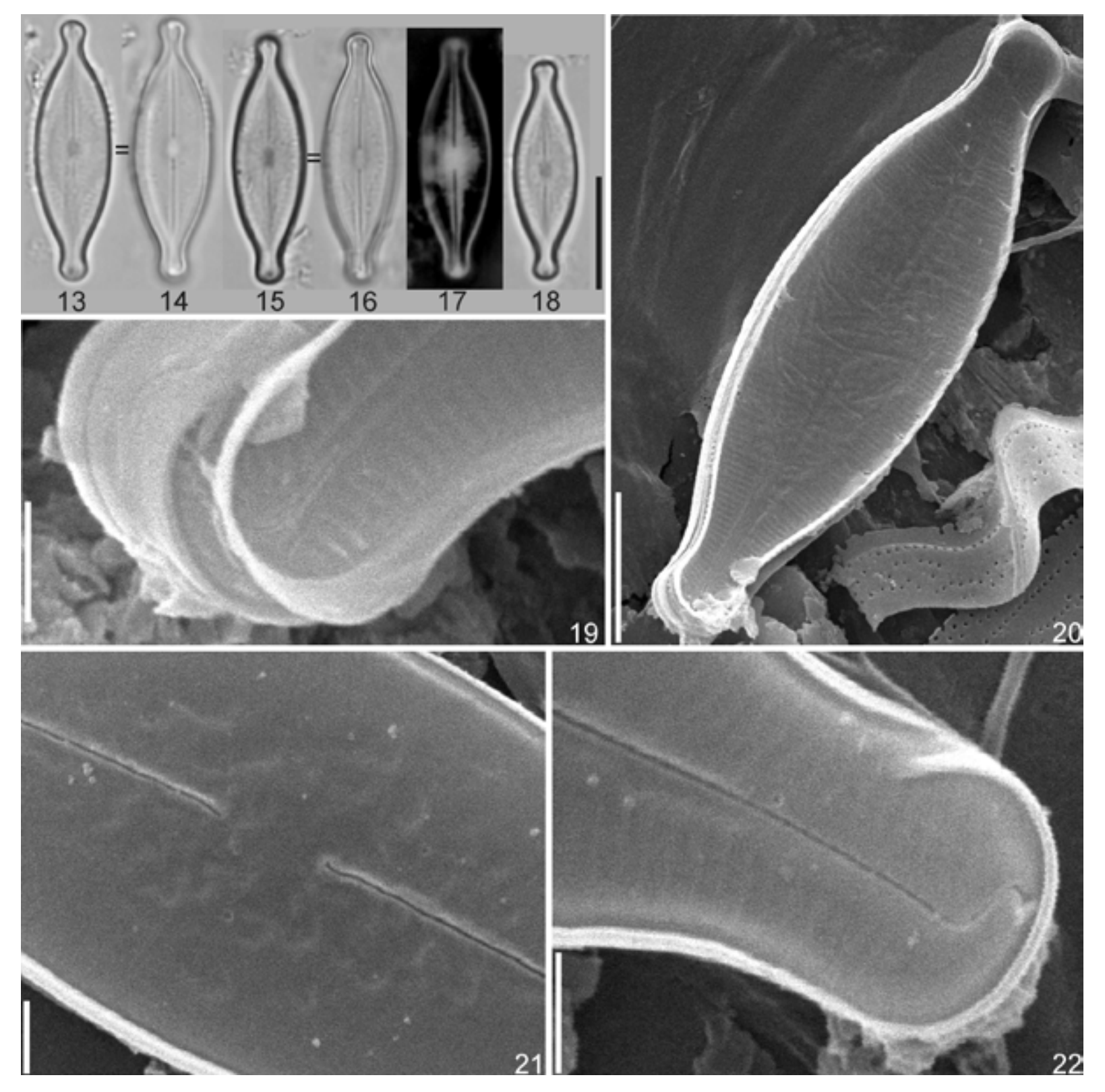

Figs 13-22. Nupela bicapitata (HUSTEDT) TREMARIN et T. LuDWIG, LM (13-18) and SEM (19-22): (19) Extremities of valve showing the
shortened raphe; (20) Overview of valve with shortened raphe; (21) Detail of central region of valve in external view; (22) External view of shortened raphe; (20) Overview of valve with shortened raphe; (21) Detail
distal end of raphe. Scale bars $10 \mu \mathrm{m}(13-18) ; 5 \mu \mathrm{m}(20) ; 1 \mu \mathrm{m}(19,21,22)$.

Nupela scissura Siver, Hamilton et Morales resembles $N$. kociolekii in the shape of valves and apices, and by the central area unilaterally expanded until the margin with c-shaped area (SIVER et al. 2007). However, $N$ scissura differs by the smaller central area, higher
number of striae $(48-58$ in $10 \mu \mathrm{m})$, straight proximal number of striae $(48-58$ in $10 \mu \mathrm{m}$ ), straight proximal
raphe ends and monoraphid frustules (SIvER et al. raphe ends and monoraphid frustules (SIVER et al. 2007).

Nupela ef. matrioschka KuLIKovsKiY, LANGEBertalo

Description: Frustules heterovalvar, slightly asymmetric about apical plane. Valves elliptical to elliptical-lanceolate with subrostrate to rounded apices, 9.3-10.3 $\mu \mathrm{m}$ long and 4.6-5.1 $\mu \mathrm{m}$ wide. Axial area linear and narrow. Central area reduced. Raphe on both valves, slightly sinuous. One valve with long raphe slits. The other valve with shorter raphe slits and slightly separated proximal endings. Proximal raphe ends externally expanded. Terminal raphe ends curved to the same side of the valve. Transapical striae radiate, ca. 35 in $10 \mu \mathrm{m}$, usually composed by discontinuou lines of areolae, ca. 39 in $10 \mu \mathrm{m}$. Outer openings of areolae transapically elongate.

Taxonomical remarks: Nupela matrioschka was described to Sphagnum bogs from Russia and has no subsequent records yet (KuLIKovskiY et al. 2009). Few exemplars found in the Brazilian samples were similar to Nupela matrioschka in shape and size of the

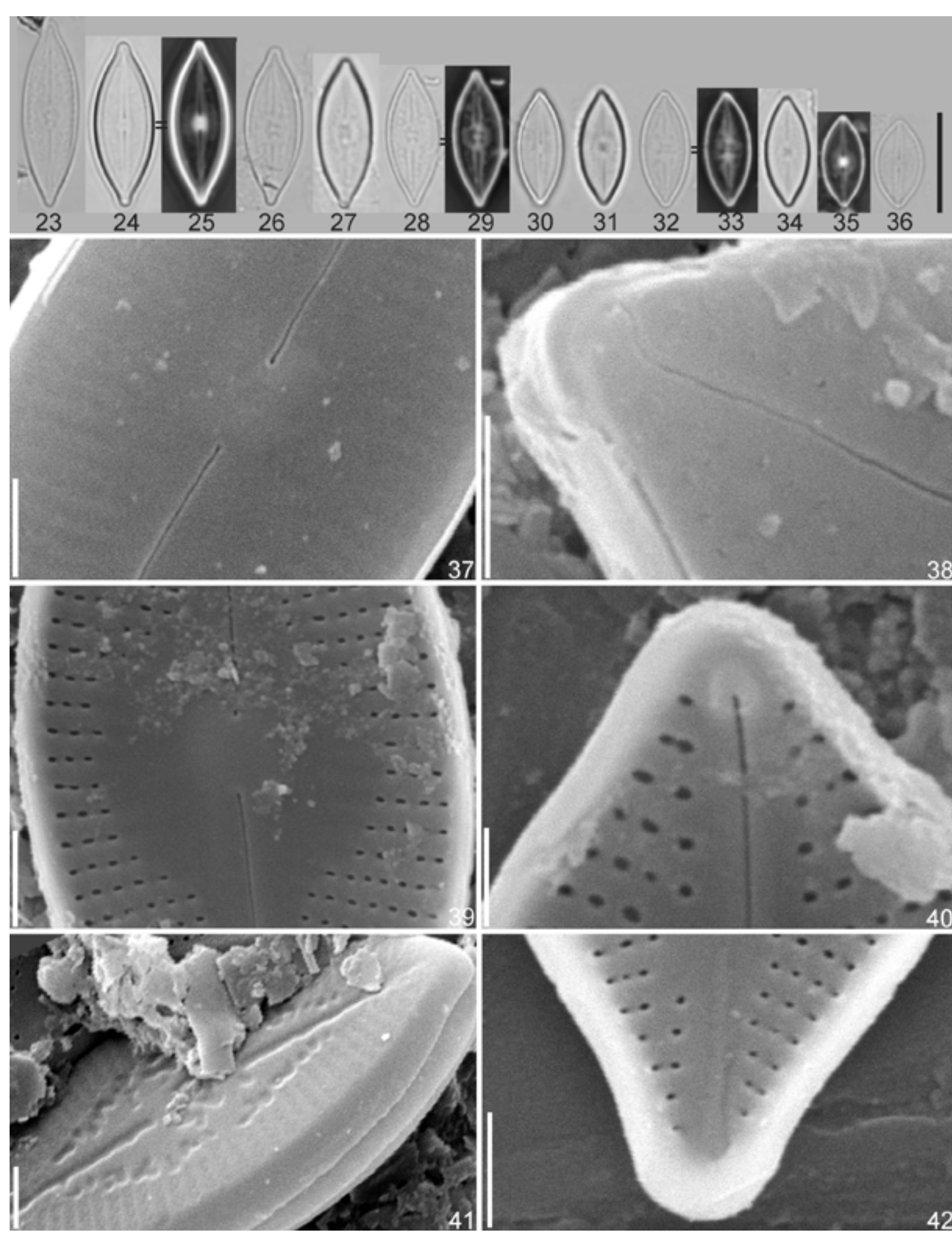

Figs 23-42. Nupela decipiens (ReiMER) PotAPovA, LM (23-36) and SEM (37-42): (37) Central area of valve in external view; (38) External view of valve without ranhe; (42) Detail of extremities of valve showing occluded fissure in internal view. Scale bars $10 \mu \mathrm{m}(23-36) ; 1$ i $(37-39,41,42) ; 0.5 \mu \mathrm{m}(40)$. 


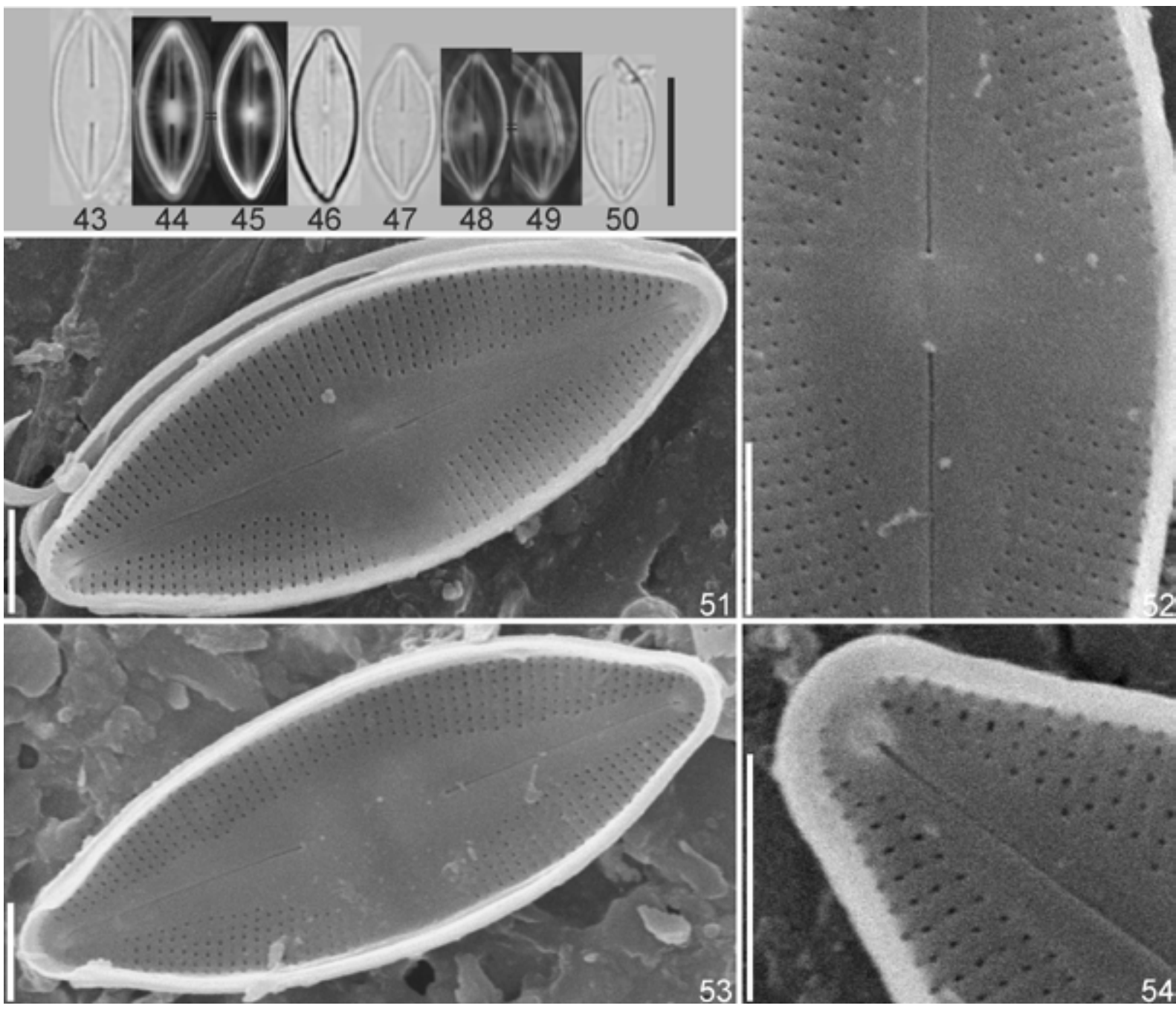

Figs 43-54. Nupela difficilis STRAuBE, TREMARIN et T. LudwiG, LM (43-50) and SEM (51-54): (48-49) Holotype; (51) Internal view of valve internal view. Scale bars $10 \mu \mathrm{m}(43-50) ; 2 \mu \mathrm{m}(51-54)$.

valves and somewhat discontinuous striation pattern. However the valves have lower density of radiate striae (non $42-48$ in $10 \mu \mathrm{m}$ ), not convergent at the apices (KuLIKovSKIY et al. 2009).

We did not find other Nupela species with similar features among the individuals studied. The scarce exemplars found in Brazilian material did not allow detailed analysis of the frustules and a possible proposal of a new taxon.

Nupela metzeltinii Tremarin et T. Ludwig sp. nov. (Figs 87-92)

Description: Frustules heterovalvar, slightly asymmetric about apical plane. Valves narrowly lanceolate with subcapitate apices, $14.8-18.9 \mu \mathrm{m}$ long and 3.7-4.1 $\mu \mathrm{m}$ wide. Axial area linear and narrow, with depressions along the raphe slits. Central area rounded. Raphe on both valves, straight. One valve with long raphe slits. The other valve with shorter raphe slits and separated proximal endings. Proximal raphe ends externally simple and straight. Terminal raphe ends curved to same side of the valve. Transapical striae radiate to slightly convergent at the apices, ca. 50 in $10 \mu \mathrm{m}$

Etymology: This species is dedicated to the diatomis Ditmar MetZeLTiN from Germany.

Holotype: Slide UPCB 47494, Diatom collection of the Botany Department, Universidade Federal do Paraná, illustrated here in Figs 89-90.

Isotype: ANSP GC26822.

Type material: Guaraguaçu river, Pontal do Paranà,

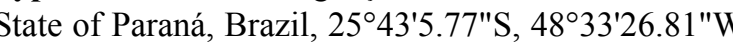
October 2003

Taxonomical remarks: Nupela metzeltinii is similar in shape and dimensions of the valves, apices an number of striae to $N$. neotropica LANGE-BERTALOT, which differs by the unilateral central area (LANGEalso have lanceolate valves and heterovalvar frustules as $N$. metzeltinii, however the former have wider valves BERTALOT \& MOSER 1994). Nupela marvanii WoJTA

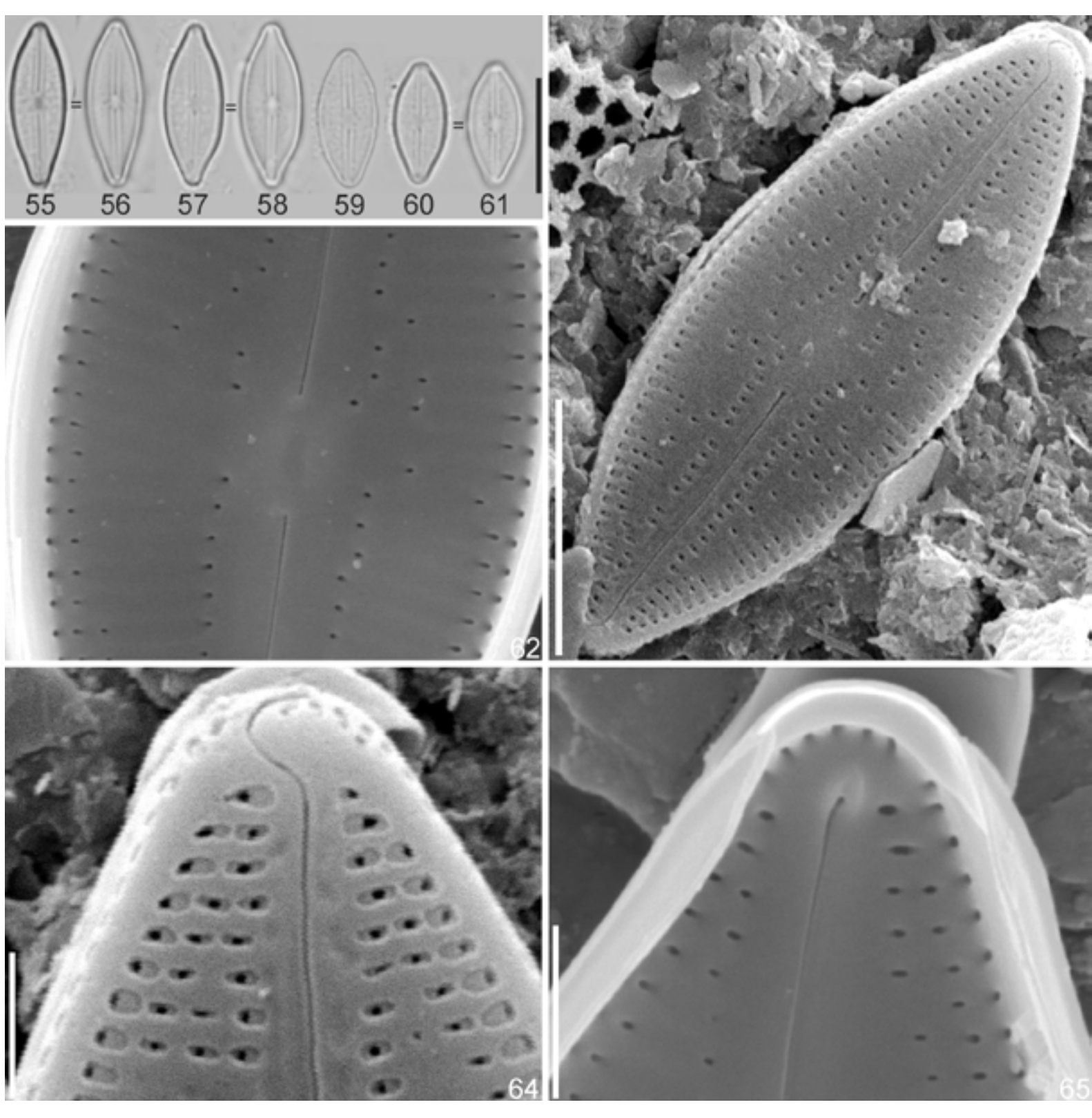

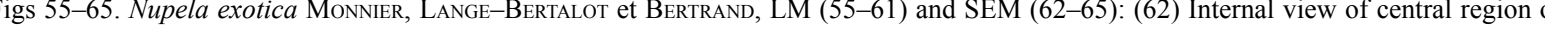
valve with longer raphe; (63) External view of valve with shorter raphe; $(64,65)$ Distal end of raphe in external and internal view, respectively.
Scale bars $10 \mu \mathrm{m}(55-61) ; 5 \mu \mathrm{m}(63) ; 1 \mu \mathrm{m}(62,64,65)$.

$(5-6 \mu \mathrm{m})$, capitate apices and a very short raphe on one of the valves (WoJTAL 2009). Nupela metzeltinii was
rare in the analyzed samples. Although it has not been rare in the analyzed samples. Although it has not been
possible a detailed description of the internal valve, no similar known species was found. The proposition of Nupela metzeltinii is justified by a set of characteristics, as heterovalvarity, lanceolate valves, subcapitates ends, raphe slits little shorter on one of the valve, and delicate depressions in the axial area.

Nupela neglecta Ponader, Lowe et Potapova (Figs 93-96)

Description: Frustules heterovalvar, slightly asymmetric about apical and transapical planes. Valves lanceolate with subrostrate apices, 10.4-10.7 $\mu \mathrm{m}$ long and width $4.1 \mu \mathrm{m}$ wide. Axial area linear and narrow. Central area small. One valve with long raphe slits The other valve with very short raphe slits and widely separated proximal endings. Proximal raphe end simple. Terminal raphe ends curved to same side of the valve and internally ending in a small helictoglossa. Transapical striae slightly radiate, 40 in $10 \mu \mathrm{m}$, composed by discontinuous lines of areolae, 2-4 per striae. Inner openings of areolae small, round or oval.

Taxonomical remarks: Nupela lesothensis (SCHOEMAN) LANGE-BERTALOT and N. jahniae-reginae LANGE-BERTALOT are the most similar species to $N$. neglecta in relation to size and shape of the valves and development of raphe, with long raphe slits on one 


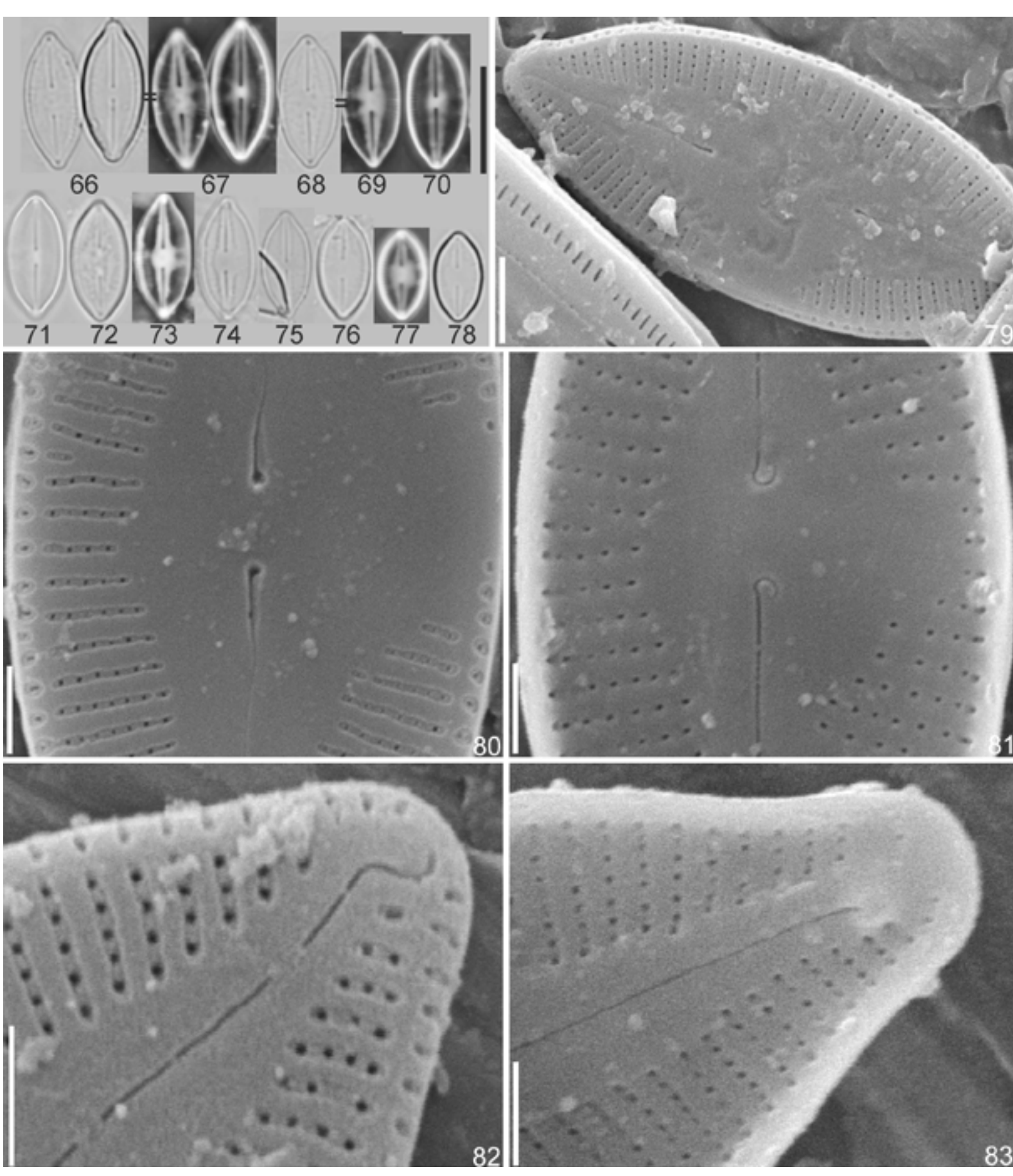

Figs 66-83. Nupela kociolekiii STRAUBE, TREMARRN et T. LuDwGG, LM (66-78) and SEM (79-83): (66-67) Holotype; (79) External view of valve with shortened raphe; $(80,81)$ Central region of valve showing the proximal ends of raphe in external and internal
Distal end of raphe in external and internal view, respectively. Scale bars $10 \mu \mathrm{m}(66-78) ; 2 \mu \mathrm{m}(79) ; 1 \mu \mathrm{m}(80-83)$.

valve and shorter on the other. These species differs mainly by the shape of apices, disposition of the areolae in the stria and number of longitudinal rows of areolae on each side of the raphe. Nupela neglecta presents slightly protracted apices, discontinuous striae and 3-4 rows of areolae while the other two species have rounded obtuse apices, continuous striae and more than 4 rows of areolae (Metzeltin \& LANGe-BertaloT 1998; Rumrich et al. 2000; Potapova et al. 2003). Nupela neglecta was described by epilithic samples from New Jersey (USA). This is the first

Nupela praecipuoides Tremarin et T. Ludwig sp. nov. (Figs 97-111)

Description: Frustules heterovalvar, slightly asymmetric about apical plane. Valves lanceolate with slightly protracted to subrostrate apices, $9.2-21.5 \mu \mathrm{m}$ slits and the other valve araphid. Raphid valve with axia record of N. neglecta to South America. long and 4.1-5.5 $\mu \mathrm{m}$ wide. One valve with long raphe

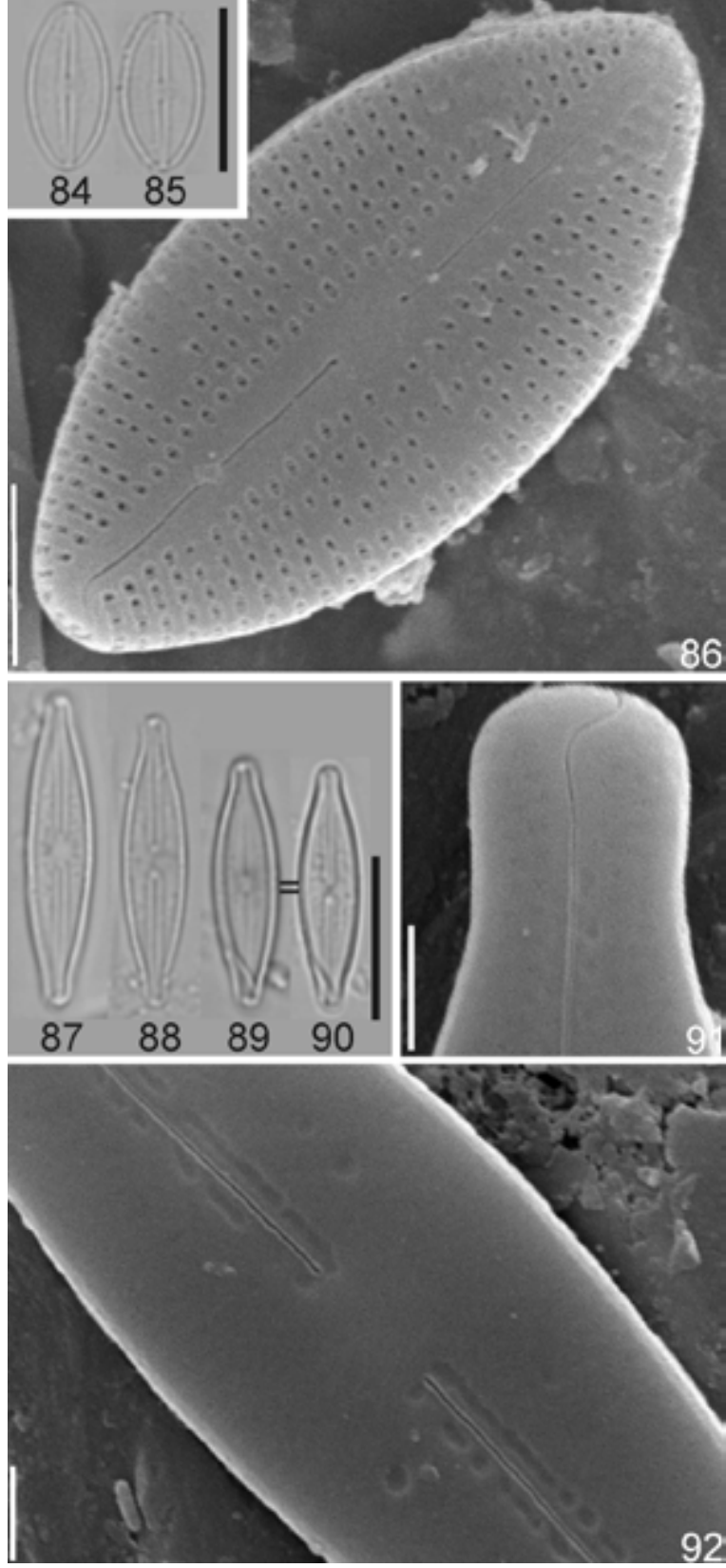

Figs 84-86. Nupela cf. matrioschka KuLIKovsKIY, LANGE-BERTALo et WITKOWSKI, LM (84-85), SEM ( 86): (86) Overview of valve.
Figs 87-92. Nupela metzzeltinii TreMArin et T. LubwiG, LM (87-90) and SEM (91-92): (89-90) Holotype; (91) Distal end of raphe in external view; (92) Detail of central region of valve showing the proximal ends of raphe in external view. Scale bars $10 \mu \mathrm{m}(84-85$,

area linear and narrow, central area rounded. Proximal raphe ends externally expanded and internally simple. Terminal raphe ends curved to same side of the valve and internally ending in small helictoglossa. Araphid valve with lanceolate axial area, smooth or generally with irregular depressions visible or not under LM. Valve araphid sometimes with internal slits occluded by silica, near the apices. Transapical striae radiate to straight at the apices, 36-38 in $10 \mu \mathrm{m}$, composed by continuous lines of areolae, 35-39 in $10 \mu \mathrm{m}$.
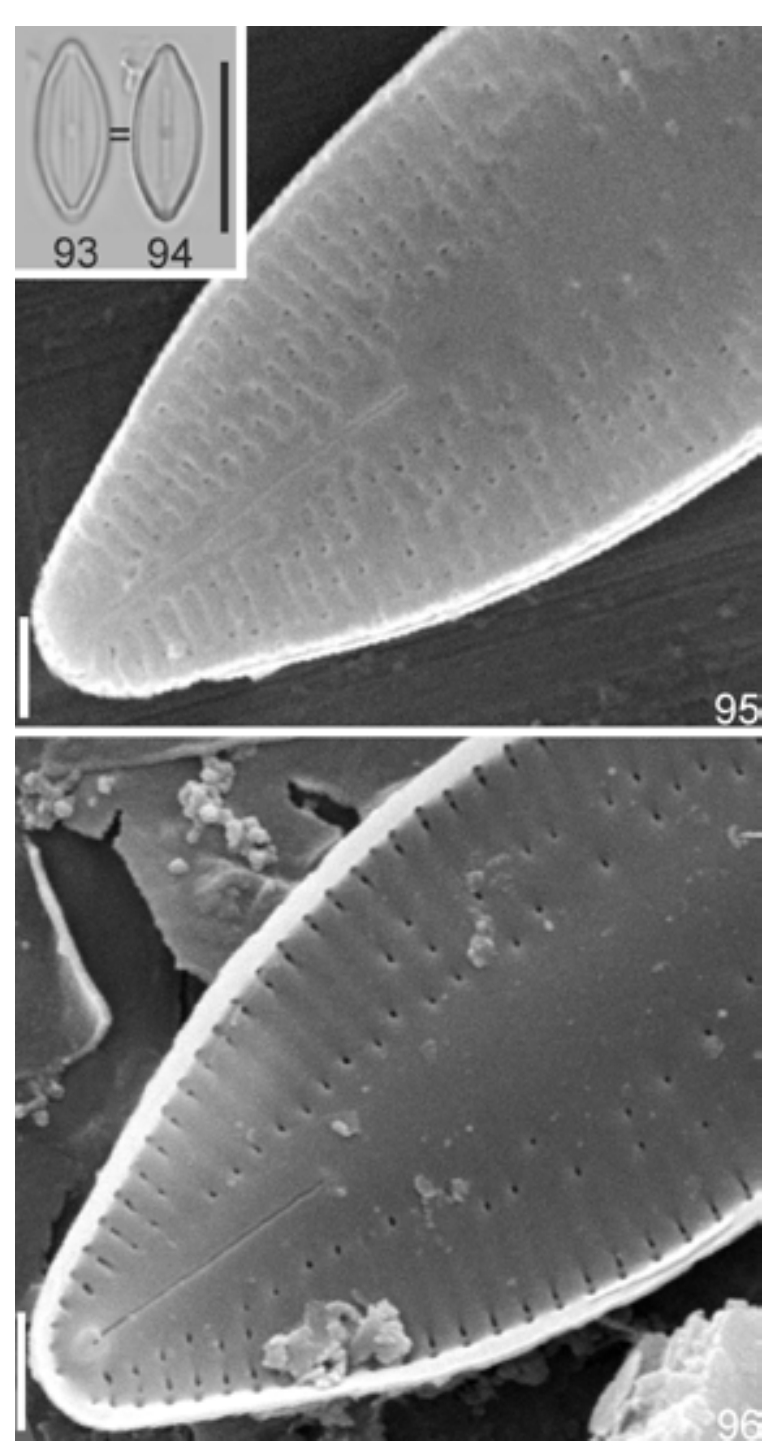

Figs 93-96. Nupela neglecta PONADER, LowE et POTAPOVA, LM (9394) and SEM (95-96): (95, 96) External and internal view of valve with shortened raphe, respectively. Scale bars $10 \mu \mathrm{m}$ (93-94); $1 \mu$

Outer openings of areolae transapically elongate and occluded by delicate hymenate layer. Inner openings of areolae small, round to oval.

Etymology: This species name was given due to it morphological resemblance to Nupela praecipua. Holotype: Slide UPCB 47494, Diatom collection of the Botany Department, Universidade Federal do Paraná, illustrated here in Fig. 103.

Isotype: ANSP GC26822.

Type material: Guaraguaçu river, Pontal do Parana State of Paraná, Brazil, $25^{\circ} 43^{\prime} 5.77^{\prime \prime S}, 48^{\circ} 33^{\prime} 26.81 " \mathrm{~W}$ October 2003.

Taxonomical remarks: The exemplars of Nupela praecipuoides were similar to the type material of N. praecipua (ReICHARDT) ReICHARDT described to Mexico. However, striae and areolae of $N$. praecipu 


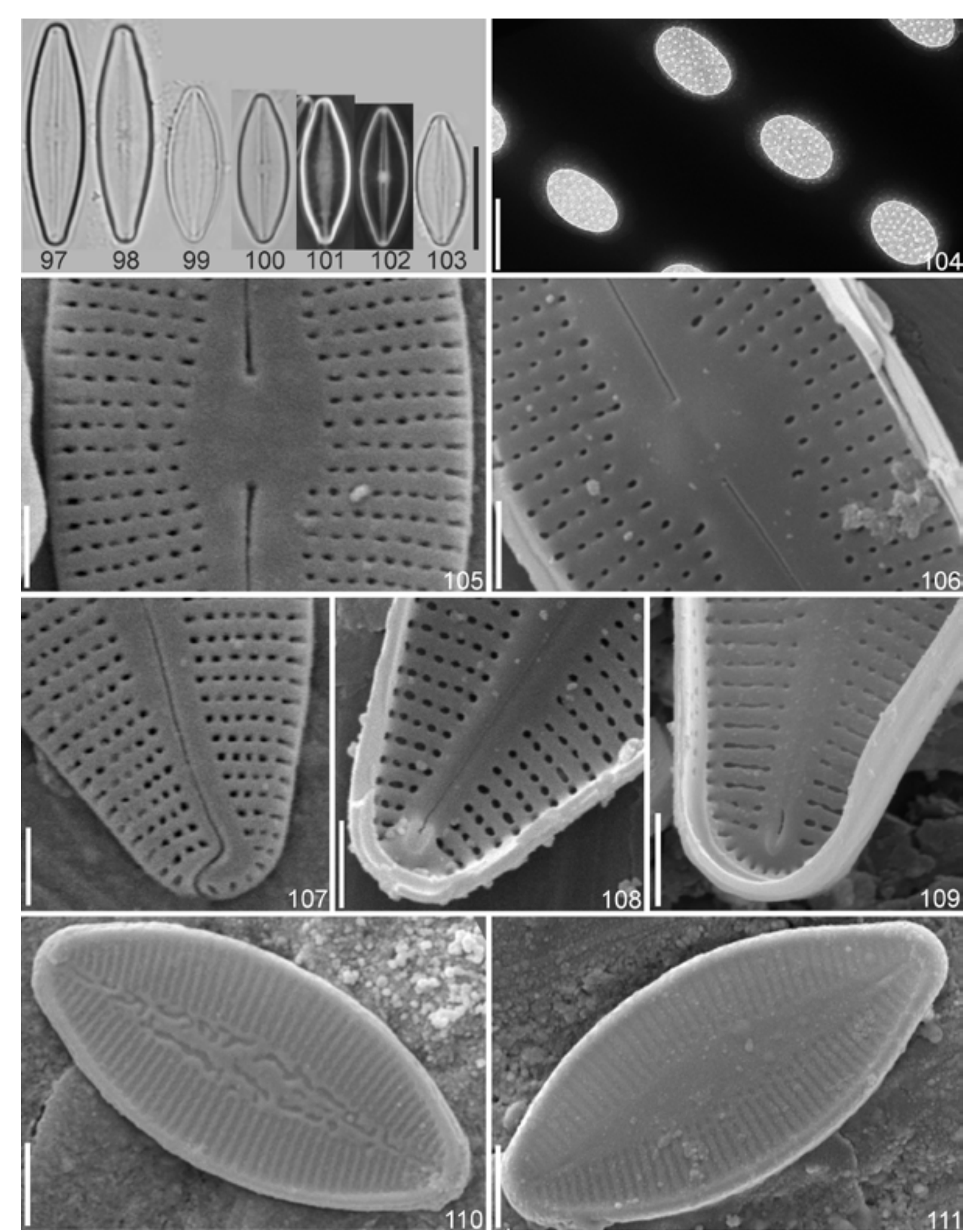

Figs 97-111. Nupela praecipuoides TREMARIN et T. LuDwIG, LM (97-103); SEM (105-111) and TEM (104): (103) Holotype; (104) Detail respectively; (107-108) Distal end of raphe in external and internal view, respectively; (109) Extremity of valve without raphe in internal view; (110-111) Valves without raphe in external and internal view, respectively. Scale bars $10 \mu \mathrm{m}$ (97-103); $2 \mu \mathrm{m}(110,111) ; 1 \mu \mathrm{m}(105-109)$ $100 \mathrm{~nm}(104)$.

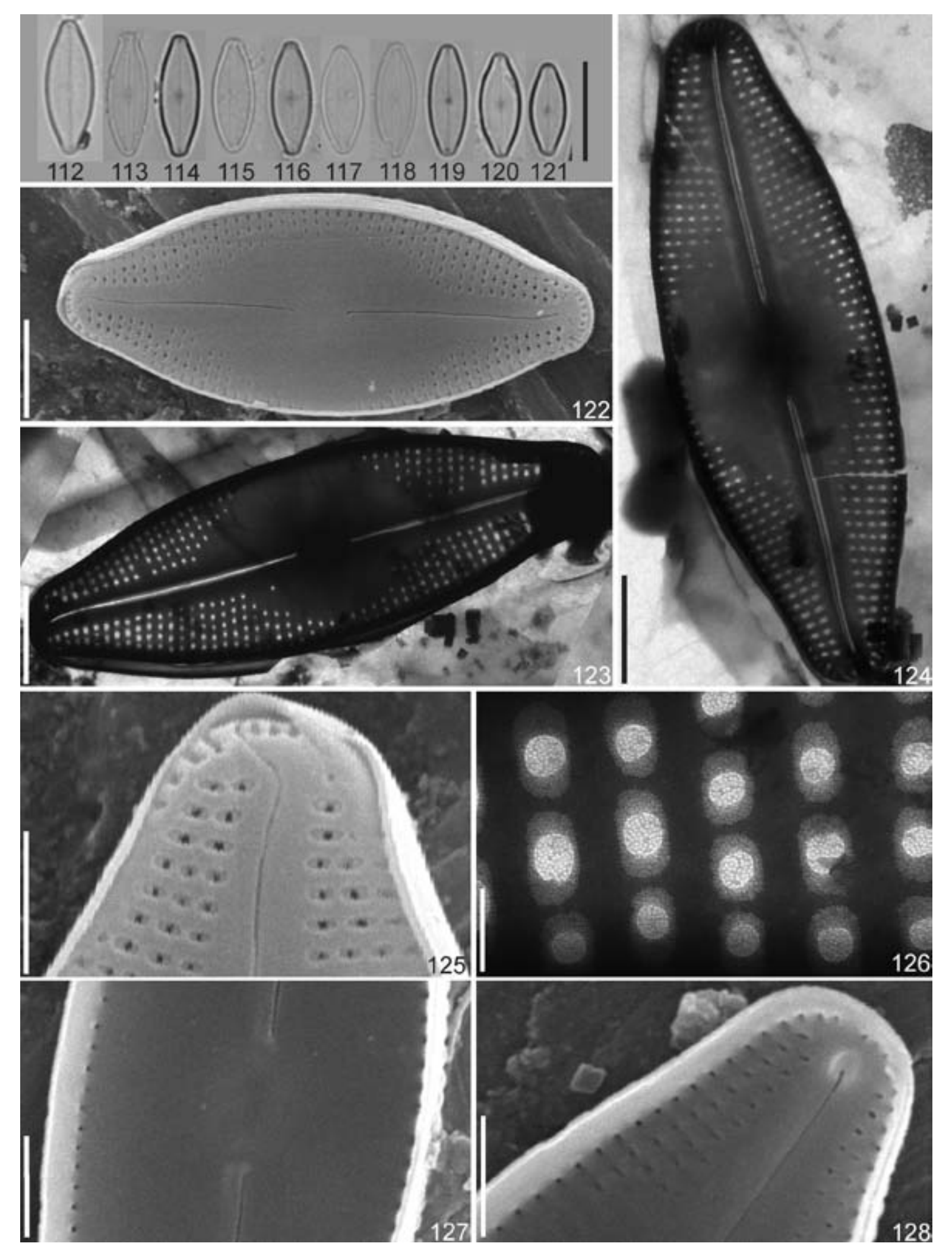

Figs 112-128. Nupela torganiae TREMARIN et T. LUDWGG, LM (112-121), SEM (122, 125, 127, 128) and TEM (123, 124, 126): (120) Holotype of raphe in external view; (126) Detail of areolae with hymenate occlusions; (127) Central region of valve showing the proximal ends of raphe
in internal view; (128) Distal end of raphe in internal view. Scale bars $10 \mu \mathrm{m}$ (Figs 112-121); $2 \mu \mathrm{m}$ (122-124); $1 \mu \mathrm{m}(125,127,128) ; 0.2 \mu \mathrm{m}$
(12) 


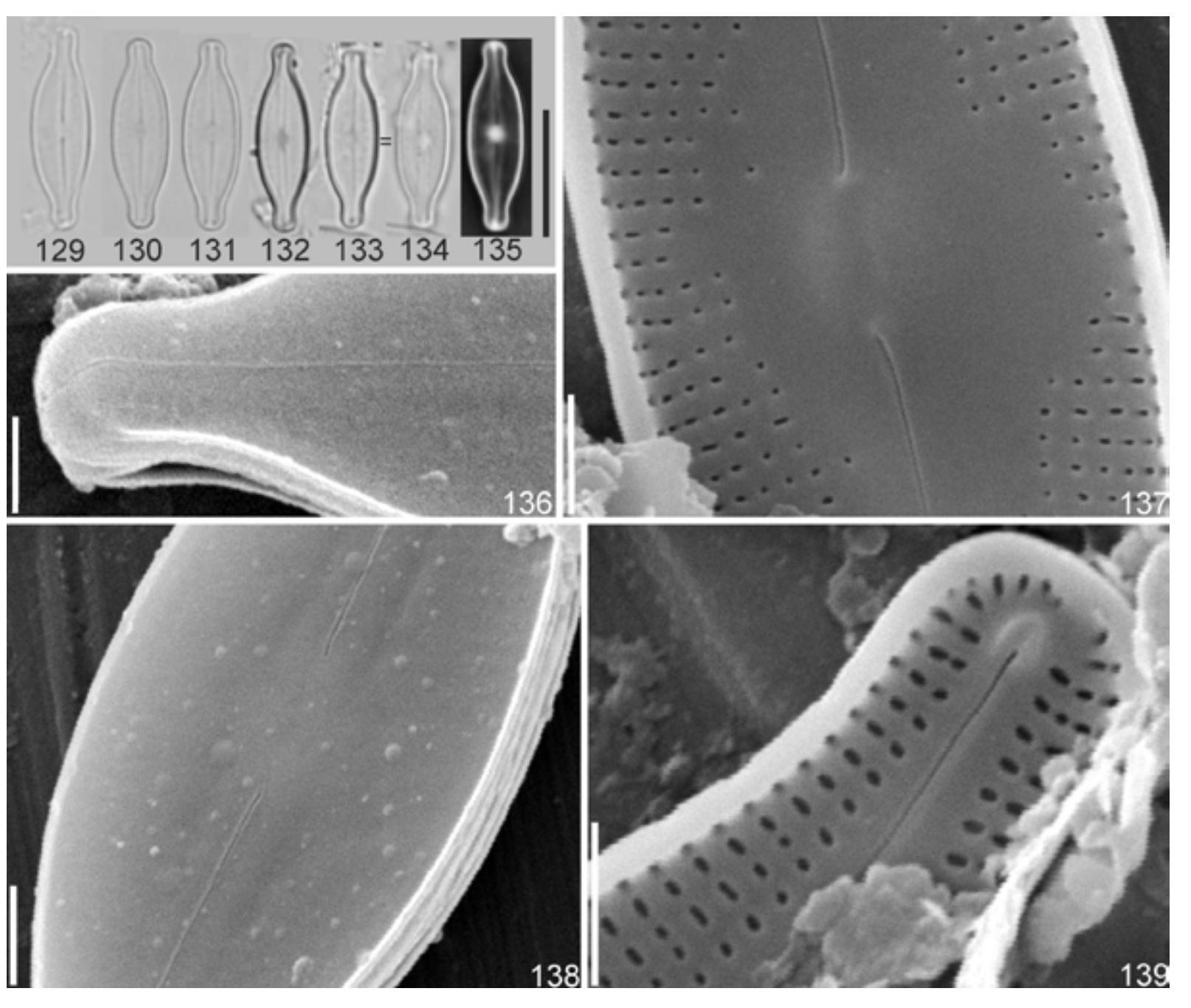

Figs 129-139. Nupela wellheri (LANGE-BERTALOT) LANGE-BERTALOT, LM (129-135) and SEM (136-139): (136) Distal end of raphe in external view; (137, 138) Central region of valve with lon
Scale bars $10 \mu \mathrm{m}(129-135) ; 1$ m $(136-139)$.

are coarser (32-36 striae/10 $\mu \mathrm{m}, 30-35$ areolae $/ 10 \mu \mathrm{m})$ than those of $N$. praecipuoides, being very conspicuous under LM. Furthermore, N. praecipua presents deeper depressions in the axial area of araphid valves, and
slightly convergent striae at the apices (REICHARDT slightly convergent striae at
1988 ; RumRICH et al. 2000).

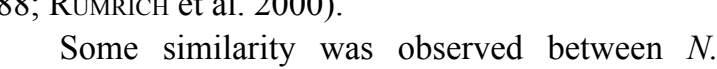
Some similarity was observed between $N$.
aecipuoides and $N$. chilensis (KrassKE) LANGEBERTALOT in relation to the valve outline and striation pattern. Nupela chilensis have wider central area, long raphe slits in both valves and lower density of striae (30-32 in $10 \mu \mathrm{m}$ ) than $N$. praecipuoides (LangeBertalot et al. 1996).

Exemplars similar to $N$. praecipuoides were recorded by RumRich et al. (2000) as Nupela spec cf. praecipua to Equador, and in south Brazil as $N$. praecipua by SCHNECK et al. (2008), TREMARIN et al. (2009) and Moresco et al. (2011)

Nupela torganiae Tremarin et T. Ludwig sp. nov. (Figs 112-128)

Description: Frustules heterovalvar, slightly asymmetric about apical plane. Valves elliptical to elliptical-lanceolate with rostrate to subrostrate apices,

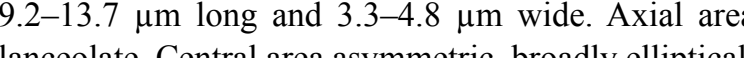
lanceolate. Central area asymmetric, broadly elliptical, unilaterally reaching the valve margin. One valve with long raphe slits and external proximal ends slightly curved to same side. The other valve with shorter raphe slits, with straight and slightly separated proximal endings. Raphe on both valves, slightly sinuous. Proximal raphe ends internally simple. Termina raphe ends curved to the same side of the valve an internally ending in a small helictoglossa. Transapica striae radiate to convergent in the apices, $45-48$ in 10 $\mu \mathrm{m}$, composed by continuous lines of areolae, 40-48 in $10 \mu \mathrm{m}$. Outer openings of areolae transapically elongate and occluded by delicate hymenate laye. Inner openings of areolae small, round to oval.
Etymology: This species is dedicated to Dr. Lezilda Carvalho ToRgan, Natural Sciences Museum of Rio Grande do Sul, Brazil.

Holotype: Slide UPCB 47494, Diatom collection of the Botany Department, Universidade Federal do Paraná, illustrated here in Fig. 120

Isotype: ANSP GC26822.

Type material: Guaraguaçu river, Pontal do Paraná, State of Paraná, Brazil, 25 $43^{\circ} 5.77^{\prime \prime S}, 48^{\circ} 33^{\prime} 26.81^{\prime \prime W}$ October 2003.

Taxonomical remarks: RuMrICH et al. (2000), based on Ecuadorian sample, found an exemplar that resembles Nupela torganiae and cited as 'Nupela spec' in plate 32, fig. 10. The lacks of SEM image of this taxon difficult the confirmation of its real identity. Some similarity was observed between $N$. torganiae and $N$. carolina in the raphe development, striation pattern, valve shape and dimensions, but the latter has central area elliptical, not expanded to the valve margin, and attenuate apices (Potapova et al. 2003)

Nupela torganiae occurred with N. amabilis in Guaraguaçu river and presented similarities in the size of valves and shape of apices, but differed in the expansion of the axial area, shape of valves and raphe. We do not find other similar species to Nupela torganiae. The new species is characterized mainly by the wide central area and the presence of raphe in both valves, being one of this slightly shorter than the other

Nupela wellneri (Lange-Bertalot) LangeBERTALOT (Figs 129-139)

\& KramMER, Biblioth. Diatomol. 15: 123-124, pl. 40, figs 28 31 , 1987.

Descrption: Frustules heterovalvar, slightly asymmetric about apical and transapical planes. Valves lanceolate with subcapitate apices, 11.8-16.6 um long and 3.7-4.4 $\mu \mathrm{m}$ wide. Axial area linear and narrow. Central area asymmetric, limited by short marginal sentral area asymmetric, limited by short marginal
striae. Raphe on both valves, straight. One valve with striae. Raphe on both valves, straight. One valve with
long raphe slits. The other valve with shorter raphe slits and separated proximal endings. Proximal raphe ends externally simple and internally deflected. Terminal raphe ends curved to same side of the valve and internally ending in small helictoglossa. Transapical striae slightly radiate to convergent in the apices, ca. 42 in $10 \mu \mathrm{m}$, composed by continuous lines of areolae, $40-50$ in $10 \mu \mathrm{m}$. Inner openings of areolae small, round to oval.

Taxonomical remarks: Nupela wellneri can be easily confused with $N$. deformis Lange-Bertalot and $N$. pallavicinii (KRassKe) Lange-Bertalot in LM, but the higher density of striae (ca. 60 in $10 \mu \mathrm{m}$ ), some small depressions in axial area and one valve with very shortened raphe slits distinguish $N$. deformis from $N$. wellneri (Potapova et al. 2003; Lange-Bertalot \& MOSER 1994). Nupela pallavicinii seems to have smaller central area than $N$. wellneri, more pronounced apices LM (LANGE-Bertalot et al. 1996). Nupela wellneri and N. bicapitata are similar concerning valve outline, bu the latter have larger valves, axial area more expanded and shorter raphe fissures.

The exemplars analyzed here agree with the protologue (length 12-14 $\mu \mathrm{m}$, width 4.0-4.8 $\mu \mathrm{m}, 45$ striae/ $10 \mu \mathrm{m}$ and 50 areolae $/ 10 \mu \mathrm{m}$ ) (LANGE-BerTaLOT \& KRAMmer 1987). Nupela wellneri was proposed to Germany, and recorded in Andes and United States Lange-Bertalot \& Krammer 1987; Rumrich et al. 2000; Potapova 2003).

Nupela amabilis, $N$. bicapitata, $N$. decipiens, N. metzeltinii, N. neglecta, $N$. torganiae and $N$. wellneri co-occured only in the Guaraguaçu river The high Nupela richness was especially found in this river, probably due to greater number of collected samples (six points and two different periods - autum and spring). In those samples we found high richnes Eunotia Ehrenberg and Pinnularia Ehrenberg (see TREMARIN et al. 2008, 2010), and also some estuarine taxa [e.g. Cyclotella stylorum Brightwell, Staurosir obtusa (HUSTEDT) GARCIA, Catenula adhaeren (MereschKowsky) Mereschкowsky, Delphineis surirella (EHRENBERG) ANDRews and Seminavis strigosa (Hustedt) Danielidis et Economou-Amilli] Among all the rivers studied, only the Guaraguaçu river presented salinity zero to 14 along the sampling points, explaining the records of estuarine taxa (TremArin al. 2010

Nupela praecipuoides was the most commo taxon, occurring in eight rivers. Nupela cf. matrioschka, $N$. neglecta and $N$. metzeltinii were considered rare in the samples, less than 10 valves were analyzed during the study. The Nupela taxa co-occured with other periphytic freshwater diatoms, as Melosira varian C. Agardh, Fragilaria fragilarioides (Grunow) CHOLNoKY, Ulnaria ulna (NItzsch) P. COMPère, Eunotia spp., Gomphonema spp., Encyonema spp. and Cocconeis spp.

Nupela species were found in all rivers located at Serra do Mar, but we have not detected them in fou (da Onça, Sertãozinho, das Pombas and do Salto rivers) from the seven analyzed lowland rivers. Generally, fas rivers with clean waters, low conductivity and neutra $\mathrm{pH}$ seem to facilitate the development of these poorly known species.

\section{ACKNombsomen}

Electron Microscopical Center of Universidade Federal do Paraná for technical assistance. To Coordenação de Aperfeicioamento de Pessoal de Nível Superior (CAPES) and
Conselho Nacional de Desenvolvimento Cientifico e Tecnológico $(\mathrm{CNPq})$ for the post doctoral and scientific productivity grants. 


\section{REFERENCES}

Alfintio, S. \& Lange-Bertalot, H. (2013): Contribution to the knowledge of the freshwater algae of Sierr Leone (Tropical West Africa): diatoms from Lom Mountains and Bumbuna Falls, the Northern Province. - Biodiversity Journal 4: 135-178.

BAHLS, L.L. (2011): Nupela potapovae sp. nov. (Bacillariophyta), a lentic alpine species

P.I.; NARDELL, M.S. \& Rocha, C.R. (2013): Diatom (Bacillariophyceae) of Iguaçu National Park, Foz do Iguaçu, Brazil. - Acta Bot. Bras. 27: 108-123.

Bes, D.; Ector, L.; Torgan, L.T. \& Lobo, E.A. (2012) Composition of the epilithic diatom flora from subtropical river, Southern Brazil. - Iheringia, Sér.

Bicudo, C.E.M. \& Menezes, M. (2006): Gênero de Algas de águas Continentais do Brasil. Chave para identificacão e descricão. - 498 pp. 2a edição, Ed. Rima, São Paulo,

BigarelLA, J.J. (2001): Contribuicão ao estudo da Planície Litorânea do estado do Paraná. Braz. - Arch. Biol. Technol. 46 pp.

Buczkó, K.; Wojtal, A. \& Magyari, E. (2013): Late quaternary Nupela taxa of retezat mts (S Carpathians), with description of Nupela pocsii sp. 436. K.E. \& CHARLES, D.F. (2000): Diatoms of low-

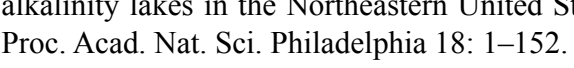

Canani, L.G.C.; Menezes, M. \& Torgan, L.C. (2011): Diatomáceas epiliticcas de águas oligotróficas e écidas do Sudeste do Brasil. - Acta Bot. Bras. 25: 130-140.
NIIER, E. \& KocioLEK, J.P. (2013): Catalogue of Diatom Names, On-line Version updated 19/07/2013.
Natian, E. \& KOCIOLK, J.P. (2013): Catalogue of Diato Californis-line at http://research calacademy org/research/diatoms/ at http://research
names/index.asp

Faria, D.M.; Tremarin, P.I. \& Ludwig, T.A.V. (2010): Datomáceas perifiticas da represa Itaqui, São José dos Pinhais, Paraná: Fragilariales, Eunotiales, Achnanthales e Gomphonema EHRENBERG. - Biota Neotropica 10: 415-427.

HENDEY, N.I. (1964): An introductory account of the smaller algae of British coastal Waters - V. Bacillariophyceac (Diatoms), Fishery Investigations Series,

HustedT, F. (1952): Neue und wenig bekannte Diatomeen. IV. - Botan. Not:: $366-410$

KulikovskiY, M.; LANGE-BertaLot, H. \& WitKowsk, A. (2009): Nupela matrioschka sp. nov., Nupela thurstonensis comb. nov. and Nupela neogracillima comb. \& nom. nov. (Bacillariophyceae): critical analysis of their morphology. - Polish Bot. J. 54

13-20.
LANGE-Bertalot, H. (1993): 85 Neue Taxa und über 100 weitere neu definierte Taxa ergänzend zur Diatomol. 27:1-454. bekannte Taxa, neae Kombinationen und Synonyme sowie Bemerkungen und Erganzungen zu d Naviculaceae. - Biblioth. Diatomol. 15: 1-289.

LANGE-BETALOI, H. \& MOSER, G. (1994): Brachysira

Lange-Bertalot, H.; Külbs, K.; Lauser, T.; NörpelSCHEMPP, M. \& WILLMANN, M. (1996): Dokumentation Diatomeen-Taxa. - In: H. LANGE-BERTALOT (ed.) Iconogr. Diatomol. 3. - 358 pp., Koeltz Scientific

Books. Königstein - Germany.
Metzeltin, D. \& L Lange-Bertalot, H. (1998): Tropical rarely known or new taxa representative of the neotropical flora. - In: H. LANGE-BERTALOT (ed.) Iconogr. Diatomol. 5. - 695 pp.. Koeltz Scientific Books, Stuttgart - Jena.

Monnier, O.; Lange-Bertalot, H. \& Bertrand, J. (2003): Nupela exotica species nova. une diatomée d'u aquarium tropical deau douce. Avec des remarques sur la biogeography du genre/Nupela exotica sp.nov. comments on the genus biogeography. - Diatom Res. 18: 273-291

Moresco, C.; Tremarin, P.I.; Ludwig, T.A.V. \& RodriguFs, L. (2011): Diatomáceas perifíticas abundantes em trềs córregos com diferentes ações antrópicas em Maringá, PR, Brasil. - Rev. Bras. Bot. 34: 359-373. Moser, G.; Lange-Bertalot, H. \& Metzeltin, D. (1998): Insel der Endemiten. Geobotanisches Phänome Neukaledomin: - Biblow. Dint the genus Nupela from the USA. - Diatom Res. 26:73-87.

POTAPOVA, M. (2013): Transfer of Achnanthes decipiens to the genus Nupela. - Diatom Res. 28: 139-142.

Potapova, M.G.; Ponader, K.C.; Lowe, R.L.; Clason, T.A. \& BAHLS, L.L. (2003): Small-celled Nupela species

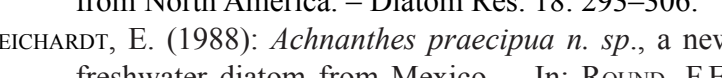
(reshwater diatom from Mexico. - In: Round, F.E. -pp. 391-396, Bristol, August 24-30, 1986. Biopres Ltd., Bristol \& Koeltz Scientific Books, Koenigstein.

Round, F.E.; CrawFord, R.M. \& Mann, D.G. (1990): The diatoms-biology e morphology of the genera. -74 pp., Cambridge University Press, Cambridge.

Rumrich, U.; LANGE-Bertalot, H. \& RuMrich, M. (2000) Diatoms of the Andes. From Venezuela to Patagonia In: L LANGE-BERTALOT, H. (ed): Iconogr Diatomol - 673 pp. A.R. G. Gantner Verlag K G. Käringste.

Sala, S.; Vouilloud, A.A.; Plata-Diaz, Y.; Pedraza, E. \& PIMIENTA, A. (2014): Nupela species (Naviculales: Bacillariophyceae) from Colombian lowland water including $N$. acaciensis nov. sp. and N. catatumbensis

SAntos, E.M.; Tremarin, P.I. \& Ludwig, T.A.V. (2011)

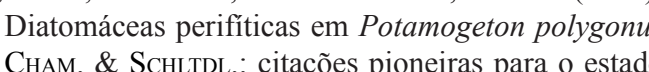
do Parań́ - Biota Neotropica 11: 303-3125.

Schneck, F.; Torgan, L.C. \& Schwarzbold, A. (2008) do Brasil. - Rodriguésia 59: 325-338.
Simonsen, R. (1974): The diatom of the Indian Ocean expedition of R/V "Meteor", 1964-1965. Berlin. Siver, P.A. \& HAMiLTon, P.B. (2005): Observations on Cape Cod, Massachusetts, USA. - Can. J. Bol. 83 Cape Cod,
$362-378$.

Siver, P.A.; Hamilton, P.B. \& Morales E.A. (2007): Notes on the Nupela (Bacillariophyceae) including the description of a new species, Nupela scissura sp. nov. and an expanded description of Nupela paludigena. Phycol. Res. 55: 125-134.

Siver, P.A.; WolfF, A.P. \& EdLund, M.B. (2010): Taxonomic descriptions and evolutionary implications of Middle Eocene pennate diatoms representing (Bacillario of the United States. Retrieved Februry 02, 2014 Available online at $\mathrm{http} \cdot / /$ westerndiatoms colorado edu/taxa/genus/Nupela

TReMARIN, P.I.; LuDWIG, T.A.V. \& Moreira-FLlHo, H. (2008): Meteor Forsch.-Ergebnisse Reihe D-Biol. 19: 1-66. the extant gencra Osmeis, Actinella and Nupela

Spauding, S. \& EDLund, M. (2008): Nupela. In: Dintom
Eunotia Ehrenberg (Bacillariophyceae) do rio

Tremarin, P.I.; Moreira-Filho, H. \& Ludwig, T.A.V. Guar). Pinnulariaceae (Bacillariophyceae) do rio Brasil - Acta Bot Bras. 24: 335-353

emarin, P.I.; Freire, E.G.; Bertolli, L.M. \& (2009): Catálogo das diatomáceas (O Theringia, Serie Botânica 64: 79-107.

VIERMAN, W. \& COMPÈRE, P. (1991): Nupela giluwensis the influence of hydrologeology and anthropogenic impacts. - In: LANGe-Bertalot, H. (ed.): Iconogr. Diatomol. 13. - 417 pp., A.R.G. Gantner Verlag K.G., Ruggell.

WOJTAL, A.Z. (2009): Nupela marvanii sp. nov., and $N$. Nupela (Bacillariophyta). - Fottea 9: 233-242.

Received June 6, 2014

Accepted November 12, 2014 Guaraguaçu, litoral do Paraná, Brasil. - Acta Bo Diatomeae) continentais do estado do Paraná. genera and sp. nov. a new genus of naviculoi

Springs from Central Europe and elsewhoms in lapidosa (KRASSKE) LANGE-BERTALOT in Poland wit 